\title{
Preliminary Evaluation of Indigenous Ricebean Landraces under Red Lateritic Belt of West Bengal, India
}

\author{
N. C. Sarkar ${ }^{1 *}$, Biswajit Ghosh ${ }^{2}$, Ratikanta Maiti ${ }^{3}$, Mhale Thorie $^{4}$, C. Rualthankhuma ${ }^{5}$ and Charan Teja K. ${ }^{1}$ \\ ${ }^{1}$ Dept. of ASEPAN, Institute of Agriculture, Visva-Bharati, PO- Sriniketan, Birbhum (Dist), West Bengal (731 236), India \\ ${ }^{2}$ Plant Biotechnology Laboratory, Post Graduate Department of Botany, Ramakrishna Mission Vivekananda Centenary \\ College, Rahara, Kolkata, West Bengal (700 118), India \\ ${ }^{3}$ Universidad Autonoma de Nuevo Leon, Facultad de Ciencias Forestales, Carr. Nac. No. 85 Km. 45, Linares, Nuevo Leon \\ 67700, Mexico \\ ${ }^{4}$ Dept. of Agronomy, SASRD, Nagaland University, Medziphema campus, PO- Medziphema, Dimapur (Dist), Nagaland \\ (797 106), India \\ ${ }^{5}$ Krishi Vigyan Kendra (KVK), Lawngtlai (Dist), Mizoram (796 891), India
}

\section{Article History}

Manuscript No. AR863

Received in $26^{\text {th }}$ July, 2014

Received in revised form $15^{\text {th }}$ December, 2014

Accepted in final form $7^{\text {th }}$ January, 2015

\section{Correspondence to}

E-mail: ncsiari@gmail.com

\section{Keywords}

Ricebean, landrace, growth, yield

\begin{abstract}
A field experiment on ricebean was conducted at the Agricultural Farm of the Institute of Agriculture (Palli Siksha Bhavana), Visva-Bharati, Sriniketan, West Bengal, India during July to December, 2013 to study the performance of few indigenous landraces collected from Nagaland and Mizoram states of India. The indigenous landraces collected are rhudi, rhuka, rhuwho-1, rhuwho-2, rhusie, rhujo, champhal, kolasib. They showed wide variability both in growth habit and yield attributes. Wide variability of test weight mainly differed the seed yield of the crop. The highest yield was recorded in rhusie cultivar $\left(21 \mathrm{q} \mathrm{ha}^{-1}\right)$ which was significantly higher than the all other cultivars like rhudi, rhuka, rhuwho-1, rhuwho-2, rhujo, champhal, kolasib. Though the rhusie cultivar test weight is low, but it recorded highest yield because of early onset of reproductive growth with more number of pickings. Rhuwho-2 cultivar recorded the second highest yield (19 $\left.\mathrm{q} \mathrm{ha}^{-1}\right)$ which was significantly higher than the other cultivars like rhudi, rhuka, rhuwho-1, rhujo, champhal, kolasib. Lowest yield was recorded in rhuwho-1 cultivars $\left(1 \mathrm{q} \mathrm{ha}^{-1}\right)$.
\end{abstract}

\section{Introduction}

Ricebean (Vigna umbellata) is a legume grown in Western, Northern and Eastern (WNE) India and Nepal. It is widely grown as an intercrop, particularly of maize and was widely grown in the past on residual water after rice. It has the potential to play a major role in intercrop systems, and can also be grown on the edges of the terraces or sloping hillsides, as well as on rice bunds and under shifting cultivation on hillsides. Ricebean is highly nutritious. The dry seeds of ricebean are goods ources of carbohydrates, proteins, minerals and vitamins. Protein in ricebean is rich in limiting amino acids methionine and tryptophan (Carvalho and Vieira, 1996). The seeds are also rich in other amino acids including valine, tyrosine and lysine. The seeds contain vitamins such as thiamine, riboflavin, niacin and ascorbic acid (Joshi et al., 2006). Ricebean contains carbohydrates 58.2-72\%, crude protein-18.3-32.2\%, ash-3.54.9\%, crude fibre-3.6-5.5\% (Buergelt et al., 2009). Generally Ricebean is recognized as a fodder crop (LI-BIRD, 2008) and it is not recognized as a food crop in India. In south Asian countries this crop is considered as one of the most important underutilized crops whose potentiality has yet to be recognized and needed intensive research investigation. In north-eastern part of the country, its landraces are abundant and local tribal people use it as one of the supplementary protein sources and consumed as the dal (cooked pulse). It is also consumed as green vegetable at green and tender stage. The crop has been found to grow irrespective of elevations and climatic 
conditions. It may be a suitable crop where soil moisture stress is a limiting factor for the growth and development of the crop. It has also been found to grow wide soil reactions. It is known as one of the hardy crops and thus can produce potential yield even in marginal land. It's potentiality yet to be harnessed for supply the growing needs of the food. Here, a preliminary trial had been conducted to find suitable cultivar most adaptable to the lateritic belt of West Bengal where moisture stress is predominant and frequent.

\section{Materials and Methods}

A Field experiment on ricebean was conducted at the Agricultural Farm of the Institute of Agriculture (Palli Siksha Bhavana), Visva-Bharati, Sriniketan, West Bengal, India situated at $23^{\circ} 39^{\prime} \mathrm{N}$ latitude, $87^{\circ} 42^{\prime} \mathrm{E}$ longitude and an elevation of $58.9 \mathrm{~m}$ above mean sea level during the period from July, 2013 to December, 2013. Objective of this trial is to study the adaptation of indigenous landraces collected from Nagaland and Mizoram states of India. The indigenous landraces collected are rhudi, rhuka, rhuwho-1, rhuwho-2, rhusie, rhujo, champhal, kolasib. All the plots are uniformly applied with $20 \mathrm{~kg} \mathrm{~N}, 40 \mathrm{~kg} \mathrm{P}_{2} \mathrm{O}_{5}$, and $40 \mathrm{~kg} \mathrm{~K}_{2} \mathrm{O} \mathrm{ha}^{-1}$ and sown on july $11^{\text {th }} 2013$ with a spacing of $45 \times 20 \mathrm{~cm}^{2}$. Total rainfall of $859.4 \mathrm{~mm}$ was received during crop growing season with average minimum weekly temperature ranged from $12.7^{\circ} \mathrm{C}$ in December to $26.0^{\circ} \mathrm{C}$ in August; while the maximum temperature varied from $27.8^{\circ} \mathrm{C}$ in December to $33.9^{\circ} \mathrm{C}$ in July. Weather parameters like sunshine hours were constant during cropping period but rainfall had shown unpredictable variation ranging from $0 \mathrm{~mm}$ in December to a maximum of $255.6 \mathrm{~mm}$ in October month which coincided with the flowering period of the crop. During the days receiving high rainfall, there was development of temporary water logging.

Growth attribute like plant height was recorded at 65 days after

\begin{tabular}{lccccc}
\hline \multicolumn{6}{l}{ Table 1: Yield contributing characters and yield of ricebean } \\
\hline Land races & $\begin{array}{c}\text { Plant } \\
\text { height } \\
\text { (65 DAS) }\end{array}$ & $\begin{array}{c}\text { No. of } \\
\text { pods } \\
\text { plant }^{-1}\end{array}$ & $\begin{array}{c}\text { No. of } \\
\text { seeds } \\
\text { pod }^{-1}\end{array}$ & $\begin{array}{c}\text { Test } \\
\text { weight }\end{array}$ & $\begin{array}{c}\text { Yield } \\
\left(\text { q ha }^{-1}\right)\end{array}$ \\
\hline Rhudi & 61 & 6 & 5 & 246 & 11 \\
Rhuka & 91 & 7 & 5 & 154 & 3 \\
Rhuwho-1 & 67 & 11 & 4 & 8 & 1 \\
Rhuwho-2 & 70 & 6 & 5 & 204 & 19 \\
Rhusie & 82 & 18 & 6 & 19 & 21 \\
Rhujo & 78 & 8 & 6 & 11 & 2 \\
Champhal & 64 & 33 & 5 & 104 & 2 \\
Kolasib & 76 & 7 & 3 & 148 & 18 \\
SEm \pm & 16.11 & 1.60 & 0.44 & 19.20 & 5.64 \\
CD $(p=0.05)$ & NS & 2.80 & 0.77 & 33.63 & 9.89 \\
\hline
\end{tabular}

sowing, but the subsequent data was not recorded due to dense foliage and trailing habitat of the most of the landraces. Yield attributes like number of pods plant ${ }^{-1}$, number of seeds pod ${ }^{-1}$, test weight, yield were studied at the time of maturity.

\section{Results and Discussion}

\subsection{Plant height}

The findings of the experiment revealed a wide variability in the growth parameters of the ricebean landraces. The plant height was recorded at 65 days after sowing and the rhuka cultivar recorded the highest plant height with $91.7 \mathrm{~cm}$. This is not favorable for pod yield whereas rhusie cultivar recorded optimum plant height which is required for getting higher pod yield. Trailing nature of most the cultivars restricted recording of plant growth height.

\subsection{Number of pods plant ${ }^{-1}$}

The highest number of pods plant $^{-1}$ were recorded in rhusie cultivar with 18 pods plant ${ }^{-1}$ ha $^{-1}$ which was significantly higher than the all other cultivars followed by rhuwho- 1 cultivar with 11 pods plant ${ }^{-1}$ which was significantly higher than the cultivars like rhudi, rhuka, rhuwho-2, rhujo, champhal, kolasib.This is because the rhusie cultivar was having lesser canopy growth and lesser foliage and more number of pods are produced than other cultivars. Lowest number of pods plant ${ }^{-1}$ was recorded in champhal and rhuwho-2 cultivars.

\subsection{Number of seeds pod ${ }^{-1}$}

The highest numbers of seeds pod ${ }^{-1}$ were recorded in both the rhusie and rhujo cultivars with average of 6 number of seeds pod $^{-1}$ which was significantly higher than the all other cultivars. Lowest number of seeds pod $^{-1}$ was recorded in kolasib and rhuwho-2 cultivars ( 3 and 4 seed pod $^{-1}$ ).

\subsection{Test weight}

The highest test weight was recorded in rhudi cultivar (246.57 $\mathrm{g}^{-1} 1000$ seeds) which was significantly higher than the all other cultivars likerhuka, rhuwho-1, rhuwho-2, rhujo, champhal, kolasib. Lowest test weight was recorded in rhuwho-1 cultivar $\left(80.06 \mathrm{~g}^{-1}\right)$.

\subsection{Yield}

The highest yield was recorded in rhusie cultivar $\left(21 \mathrm{q} \mathrm{ha}^{-1}\right)$ which was significantly higher than the all other cultivars like rhudi, rhuka, rhuwho-1, rhuwho-2, rhujo, champhal, kolasib. Though the rhusie cultivar test weight is low, but it recorded highest yield because of early onset of reproductive growth with more number of pickings. This crop in fact produced lesser canopy growth when compared with other landraces. Rhuwho-2 cultivar recorded the second highest yield (19 q $\mathrm{ha}^{-1}$ ) which was significantly higher than the other cultivars like rhudi, rhuka, rhuwho-1, rhujo, champhal, kolasib. Lowest 
yield was recorded in rhuwho-1 cultivars $\left(1 \mathrm{q} \mathrm{ha}^{-1}\right)$.

\section{Conclusion}

Landraces of ricebean has shown wide variability both in growth habit and yield attributes. Wide variability of test weight differs in the seed yield, however yield atributes proved rhusie as the highest yielder. Further investigation is necessary to conform the adaptability and yield potentiality of this crop.

\section{References}

Buergelt, D., von Oppen, M., Yadavendra, J.P., 2009. Quality parameters in relation to consumer's preferences in ricebean. Presentation at the International Conference on Grain Legumes: Quality Improvement, Value Addition and Trade, February 14-16, 2009, Kanpur, India.

Carvalho, N.M., de, Vieria, R.D., 1996. Ricebean [Vigna umbellata (Thunb.) Ohwi and Ohashi]. In: Nkowolo, E., Smartt, J. (Eds.), Legumes and oilseeds in nutrition. Chapman and Hall, 222-228.
Joshi, K.D., Bhandari, B., Gautam, R., Bajracharya, J., Hollington, P.A., 2006. Ricebean: a multipurpose Underutilized legume. Paper presented at $5^{\text {th }}$ International Symposium on New Crops and Uses: Their roles in a rapidly changing world. Organized by the Centre for Underutilized Crops, University of Southampton in partnership with National Non-food Crops Centre and the Tropical Agricultural Association.

LI-BIRD. 2007. Food security through ricebean research in India and Nepal (FOSRIN). Periodic activity report. Local Initiatives for Biodiversity, Research and Development (LI-BIRD), Pokhara, Nepal.

LI-BIRD. 2008. Food security through ricebean research in India and Nepal (FOSRIN). Periodic activity report. Local Initiatives for Biodiversity, Research and Development (LI-BIRD), Pokhara, Nepal. 